\title{
ANSERINE AND CARNOSINE CONTENTS IN MUSCULAR TISSUE OF RAT AND RABBIT
}

\author{
Nanaya TAmaki, Masayuki Nakamura, Mitsuko Harada, \\ Keiko Kimura, ${ }^{1}$ Hiroko Kawano, and Takao Hama ${ }^{2}$ \\ ${ }^{1}$ Laboratory of Nutritional Chemistry, Faculty of Nutrition and \\ ${ }^{2}$ Laboratory of Physiological Chemistry, Faculty of Pharmacy, \\ Kobe-Gakuin University, Tarumi-ku, Kobe 673, Japan
}

(Received September 17, 1976)

\begin{abstract}
Summary The effect of various muscle conditions on anserine and carnosine contents suggests that these peptides have some physiological role in muscular functions. These conditions are: 1) Although the anserine content in rat gastrocnemius muscle was not changed by ischiamic denervation, the carnosine content was significantly decreased. Carnosinase activity in the denerved gastrocnemius muscle was two times stronger than that of intact gastrocnemius muscle. 2) Carnosine content in rat gastrocnemius muscle was also decreased by forced swimming exercise. 3) Neither anserine nor carnosine was detected in sarcoma and granuloma. 4) In rabbit, anserine and carnosine contents in white muscle fibers were $12-17$ and 1-2 $\mu \mathrm{mole} / \mathrm{g}$ of wet tissue and were approximately 10 and 2 times more than those in red muscle fibers, respectively.
\end{abstract}

It is well known that the peptides anserine ( $\beta$-alanyl- $\mathrm{N}^{\pi}$-methylhistidine) and carnosine $(\beta$-alanylhistidine) are found in the skeletal muscle of many species of animals (1-3). Biosyntheses of anserine and carnosine in skeletal muscle were first studied by WinNicK et al. (4) and KALYANKer et al. $(5,6)$. By extensive scrutiny, we have shown that anserine is synthesized from $\beta$-alanine and $\mathrm{N}^{\pi}$ methylhistidine and then converted to carnosine in rat $(7,8)$.

The physiological roles of anserine and carnosine have not been well established. It seems very interesting to study the anserine and carnosine contents in skeletal muscle under various conditions, because anserine and carnosine can be found only in skeletal muscle in normal rat. It has already been reported that carnosine content in rat gastrocnemius muscle is remarkably decreased by a low-protein diet, but on the contrary, anserine content is not affected (9).

${ }^{1}$ 玉木七八，中村允之，原田光子，木村恵子， ${ }^{2}$ 川野博子，浜 堯夫 
In this paper, the contents of anserine and carnosine in rat gastrocnemius muscle, during the restriction and stimulation of muscular contraction, are described. Furthermore, the contents of these peptides in sarcoma and granuloma, which are the multiple growth cells in muscle, are compared with those of gastrocnemius itself because carnosine is also synthesized in tumors (10) and it enhances the formation of granuloma (11). Moreover, considering the physiological difference between the fast and slow twitches, the contents of anserine and carnosine in the white and red muscles of rabbit are compared.

\section{MATERIALS AND METHODS}

Chemicals. All chemicals used were of analytical grade and were purchased from Nakarai Chemicals Ltd., Kyoto, unless stated otherwise. Standard anserine nitrate and carnosine were obtained from Sigma, U.S.A. The reagents for the amino acid analysis were purchased from E. Merck, W. Germany.

Animals. Wistar strain male rats, weighing between 50 and $60 \mathrm{~g}$, unless stated otherwise, and white strain male rabbits, weighing approximately $1 \mathrm{~kg}$, were used. They were housed in individual screen-bottom cages in a room with regulated temperature $\left(23 \pm 1{ }^{\circ} \mathrm{C}\right)$, air $(50 \%$ fresh air with $60 \%$ moisture) and lighting $(12 \mathrm{hr}$ light and $12 \mathrm{hr}$ dark). The animals were given commercial food pellets (CLEA Japan, Inc.) and water ad libitum. Each group consisted of three to five animals.

Ischiamic denervation. Under ether anesthesia, one side of the rump of a rat was incised and approximately $1 \mathrm{~cm}$ of the sciatic nerve fibers was cut out. The opposite posterior leg was left intact. Untreated control and operated rats were housed for definite terms and then killed by decapitation. The gastrocnemius muscles were quickly removed, washed with physiological saline, chilled at $0^{\circ} \mathrm{C}$, weighed and stored at $-25^{\circ} \mathrm{C}$ before use.

Gibney's fixation. One leg of a rat was fixed with a commercial Gibney's bandage for one week. Then, the animal was killed by decapitation. The gastrocnemius muscles of the fixed leg and another intact leg were quickly removed.

Forced muscular contraction. The electric stimulation and the swimming methods were adopted for the stimulation of muscular contraction.

1) A rat was fixed on a plate and contact was made with electrode needles on the upper and lower parts of the gastrocnemius muscle. The muscle was electrically stimulated at a frequency of five times per second with an electrostimulation apparatus (Fugi Shassis) for six hours per day. This treatment was administered to the rat for five days at a fixed time. Immediately after stimulation on the fifth day, the animal was killed and the stimulated muscle was removed.

An isolated normal gastrocnemius muscle was electrically stimulated at a frequency of five times per second, in vitro, until no more response to the current was observed.

2) Male rats, weighing approximately $200 \mathrm{~g}$, were forced to swim in $23-24^{\circ} \mathrm{C}$ 
temperature once a day until exhausted. The swimming exercise was continued for three weeks. The body weight was measured before and after the daily swimming exercise. At the time of exhaustion in the final swimming exercise, the rats were killed, and the gastrocnemius muscle was removed immediately.

Granulation. A granulation was made by the agar method (12). One small spoonful of agar was transplanted into the subcutaneous tissue of the back of a rat. After one week the rat was decapitated and the granuloma was removed, washed with physiological saline, and weighed.

Sarcoma. Walker carcinosarcoma was transplanted into the gastrocnemius of rat. After one week the rat was decapitated and the sarcoma was removed. The gastrocnemius of the opposite leg was used as a control.

White and red muscle fibers. Rabbits were killed by decapitation, and the gastrocnemius, the adductor magnus and the latissimus dorsi muscles were quickly removed. Each muscle was separated into either white or red muscle fibers (13) and then washed with chilled physiological saline and stored at $-25^{\circ} \mathrm{C}$ before use.

Analysis of $\beta$-alanine, histidine, anserine and carnosine. Rat gastrocnemius muscle, rabbit white and red muscles, a granuloma and a sarcoma were homogenized with $80 \%$ ethanol and allowed to stand for $3 \mathrm{hr}$ at $60^{\circ} \mathrm{C}$. After centrifugation, the supernatant was prepared as a sample for amino acids and peptides analysis according to a previous paper (7) and the precipitate was provided as a sample for the estimation of DNA, RNA and protein contents. The amino acids and peptides were determined with an autoanalyzer (Hitachi KLA-3B type).

Estimation of DNA, RNA and protein. The precipitate was washed three times as follows; in absolute ethanol, ethanol: ether $(3: 1)$ and absolute ether in that order. Then it was washed once with ice cold $0.4 \mathrm{~N} \mathrm{HClO}_{4}$ and twice with cold $0.2 \mathrm{~N}$ $\mathrm{HClO}_{4}$. To the precipitate, $15 \mathrm{ml}$ of $0.4 \mathrm{~N} \mathrm{HClO}_{4}$ was added, and then the suspension was incubated for $15 \mathrm{~min}$ at $90^{\circ} \mathrm{C}$ to solubilize nucleic acid. After cooling, the hydrolysate was centrifuged to remove the precipitated protein. The precipitate was washed twice with $5 \mathrm{ml}$ of $0.2 \mathrm{~N} \mathrm{HClO}_{4}$. The washing was then added to the supernatant fraction. The combined supernatants were used for the determination of nucleic acid. Nucleic acid content was determined from the optical density at $262 \mathrm{~nm}$. The determination of DNA was carried out by the deoxypentose assay according to BURTON (14). The content of RNA was calculated by reducing DNA content from the total nucleic acid content.

The precipitated protein after nucleic acid hydrolysis was dried with absolute ethanol, ethanol: ether $(3: 1)$ and absolute ether in that order, and then the protein content was estimated by determins the dry weight.

Estimation of creatinine. Using the sample solution for amino acid and dipeptide analysis, creatinine was determined according to the FoLIN-WU method (15).

Carnosinase activity. The gastrocnemius muscles of denerved rat and normal

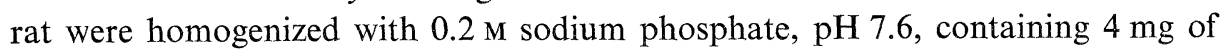
amplcillin and $2 \mathrm{mg}$ of cloxacillin per $\mathrm{ml}$ of the buffer. The homogenate was 
passed through doubly layered gauze and the filtrate was used as an enzyme solution. Reaction mixture containing $1 \mathrm{ml}$ of carnosine solution $(2 \mu \mathrm{moles} / \mathrm{ml}$ of $0.2 \mathrm{M}$ potassium phosphate, $\mathrm{pH} \mathrm{7.6)}$ and $1 \mathrm{ml}$ of enzyme solution was incubated for 1,4 , and $24 \mathrm{hr}$ at $37^{\circ} \mathrm{C}$. After incubation, $8 \mathrm{ml}$ of ethanol was added, and the solution was mixed and centrifuged. The precipitate was washed twice with $5 \mathrm{ml}$ of $80 \%$ ethanol. The supernatants were pooled and dried in vacuo. The residue was dissolved with citrate buffer, $\mathrm{pH} 2.2$, for amino acid analysis. The enzymic activity was estimated by the production of $\beta$-alanine and histidine and the reduction of carnosine. The protein was determined by the biuret method (16).

\section{RESULTS}

Effect of ischiamic denervation on anserine and carnosine contents of rat gastrocnemius muscle

As shown in Table 1, the wet weight of gastrocnemius muscle was decreased in the denerved leg, in spite of the increased weight in the intact one. The content

Table 1. Effect of denervation on weight and protein, DNA and RNA contents of rat gastrocnemius muscle.

\begin{tabular}{ccccccc}
\hline Treatment & $\begin{array}{c}\text { Weeks } \\
\text { after } \\
\text { operation }\end{array}$ & $\begin{array}{c}\text { Number Wet weight } \\
\text { used }\end{array}$ & $\begin{array}{c}\text { Protein } \\
\text { g/wet }\end{array}$ & $\begin{array}{c}\text { DNA } \\
\text { tissue }(\mathrm{g})\end{array}$ & $\begin{array}{c}\text { RNA } \\
\text { tissue }(\mathrm{g})\end{array}$ & $\begin{array}{c}\text { mg/wet } \\
\text { tissue (g) }\end{array}$ \\
\hline $\begin{array}{c}\text { Normal rats } \\
\text { (non-treated) }\end{array}$ & 0 & 6 & $0.384 \pm 0.017$ & $0.232 \pm 0.013$ & $0.968 \pm 0.116$ & $1.185 \pm 0.288$ \\
$\begin{array}{c}\text { Treated rats } \\
\text { Intact side }\end{array}$ & 1 & 5 & $0.473 \pm 0.057$ & $0.223 \pm 0.004$ & $0.851 \pm 0.039$ & $1.151 \pm 0.154$ \\
& 2 & 5 & $0.652 \pm 0.052$ & $0.217 \pm 0.013$ & $0.813 \pm 0.092$ & $1.170 \pm 0.093$ \\
& 3 & 5 & $0.974 \pm 0.071$ & $0.185 \pm 0.003$ & $0.887 \pm 0.033$ & $1.016 \pm 0.055$ \\
Denerved side & 1 & 5 & $0.310 \pm 0.027^{*}$ & $0.228 \pm 0.011$ & $1.421 \pm 0.089^{*}$ & $1.170 \pm 0.275$ \\
& 2 & 5 & $0.307 \pm 0.005^{* *}$ & $0.209 \pm 0.013$ & $1.715 \pm 0.081^{* *}$ & $1.427 \pm 0.221$ \\
& 3 & 5 & $0.319 \pm 0.070^{* *}$ & $0.208 \pm 0.034$ & $1.917 \pm 0.263^{* *}$ & $1.249 \pm 0.036$ \\
Normal rats & & & & & & \\
(non-treated) & 3 & 6 & $0.814 \pm 0.093$ & $0.205 \pm 0.023$ & $0.994 \pm 0.038$ & $0.994 \pm 0.041$ \\
\hline
\end{tabular}

Mean \pm standard error.

* $p<0.05$ compared to intact side, ** $p<0.01$ compared to intact side.

(mg) of DNA per wet tissue ( $\mathrm{g}$ ) of the denerved gastrocnemius muscle was 1.7 times as much as that of intact gastrocnemius muscle in the first week after operation and was 2.2 times in the third week. However, the content (mg) of RNA per wet tissue (g) was constant over the experimental periods.

Table 2 shows anserine and carnosine contents of rat gastrocnemius muscle after ischiamic denervation. By denervation, the anserine content slightly increased and carnosine content decreased significantly. As shown in Fig. 1, carnosine versus anserine ratio obviously decreased and was one-tenth in the third week after 
Table 2. Effect of denervation on anserine and carnosine contents in rat gastrocnemius muscle.

\begin{tabular}{cccc}
\hline Treatment & $\begin{array}{c}\text { Weeks after } \\
\text { operation }\end{array}$ & $\begin{array}{c}\text { Anserine } \\
\mu \text { mole/wet tissue }(\mathrm{g})\end{array}$ & $\begin{array}{c}\text { Carnosine } \\
\mu \text { mole/wet tissue (g) }\end{array}$ \\
\hline $\begin{array}{c}\text { Normal rats } \\
\text { (non-treated) }\end{array}$ & 0 & $2.546 \pm 0.679$ & $5.571 \pm 0.971$ \\
$\begin{array}{c}\text { Treated rats } \\
\text { Intact side }\end{array}$ & 1 & $3.037 \pm 0.236$ & $7.407 \pm 0.397$ \\
& 2 & $2.712 \pm 0.502$ & $6.183 \pm 0.263$ \\
Denerved side & 3 & $3.944 \pm 0.404$ & $6.109 \pm 0.973$ \\
& 1 & $3.915 \pm 0.713$ & $4.261 \pm 0.951^{*}$ \\
& 2 & $3.825 \pm 0.533$ & $1.478 \pm 0.212^{* *}$ \\
Normal rats & 3 & $4.615 \pm 0.486$ & $0.899 \pm 0.164^{* *}$ \\
(non-treated) & 3 & $4.545 \pm 0.679$ & $7.231 \pm 0.228$ \\
\hline
\end{tabular}

Mean \pm standard error.

$* p<0.05$ compared to intact side, $* * p<0.01$ compared to intact side.

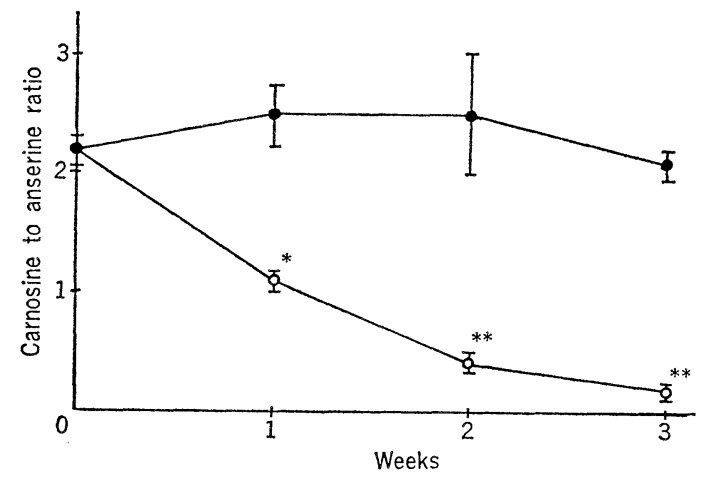

Fig. 1. Effect of denervation on the ratio of carnosine to anserine in rat gastrocnemius muscle. , denerved; $\bullet$, intact. Mean \pm standard error, ${ }^{*} p<0.05, * * p<0.01$.

denervation, compared to that before treatment. No difference of anserine and carnosine contents of control rat gastrocnemius was found in the third week compared to that of the intact side of the gastrocnemius muscle of the treated rat. The contents of $\beta$-alanine and histidine, $0.470 \pm 0.201$ and $0.300 \pm 0.131 \mu \mathrm{moles} /$ wet tissue $(\mathrm{g})$, respectively, in rat gastrocnemius muscle in the third week after ischiamic denervation were not affected compared with those of normal rat $(0.300 \pm 0.131$ and $0.262 \pm 0.031 \mu$ moles/wet tissue (g), respectively).

Carnosinase activity of denerved gastrocnemius muscle was $3.6 \mathrm{nmoles} / \mathrm{min} /$ wet tissue $(\mathrm{g})$, showing that the activity in the denerved gastrocnemius muscle is stronger than that in the intact gastrocnemius muscle $(1.5 \mathrm{nmoles} / \mathrm{min} /$ wet tissue $(\mathrm{g}))$. Carnosinase activity per protein in the former was two times as much as in the latter. 
Anserine and carnosine contents of gastrocnemius muscle after Gibney's fixation were also estimated. At one week after the fixation, carnosine content of muscle decreased to about $80 \%$ of that of intact (non-fixed side) muscle (Table 3 ). The anserine content was not changed by this treatment (Table 3 ).

Table 3. Effect of restriction and stimulation of muscular activity on anserine and carnosine contents in rat gastrocnemius muscle.

\begin{tabular}{ccc}
\hline Treatment & $\begin{array}{c}\text { Anserine } \\
\mu \text { mole/wet tissue }(\mathrm{g})\end{array}$ & $\begin{array}{c}\text { Carnosine } \\
\mu \text { mole/wet tissue (g) }\end{array}$ \\
\hline Experiment I & & \\
Control & $4.492 \pm 0.687$ & $4.076 \pm 1.095$ \\
Stimulated (1) & $4.486 \pm 0.593$ & $2.328 \pm 0.660^{*}$ \\
Restricted (2) & $4.276 \pm 0.327$ & $3.204 \pm 0.504$ \\
Experiment II & & \\
Control & $5.370 \pm 0.364$ & $4.526 \pm 0.744$ \\
Stimulated (3) & $4.564 \pm 0.641$ & $5.838 \pm 0.443$ \\
Stimulated (4) & $4.820 \pm 0.111$ & $4.703 \pm 0.345$ \\
\hline
\end{tabular}

Mean \pm standard error, $* p<0.05$.

(1), daily swimming test for 3 weeks; (2), restricted by Gibney's fixation; (3), electrical stimulation in vivo; (4), electrical stimulation in vitro.

Effect of forced muscular contraction on anserine and carnosine contents of rat gastrocnemius muscle

No effect of electric stimulation on anserine and carnosine contents in rat gastrocnemius muscle was found in vivo and in vitro (Table 3 ).

Figure 2 shows that the effect of forced swimming exercise on rat body weight. The difference in body weight was about 5 to $12 \mathrm{~g}$ before and after the swimming test. The forced exercise produced growth retardation.

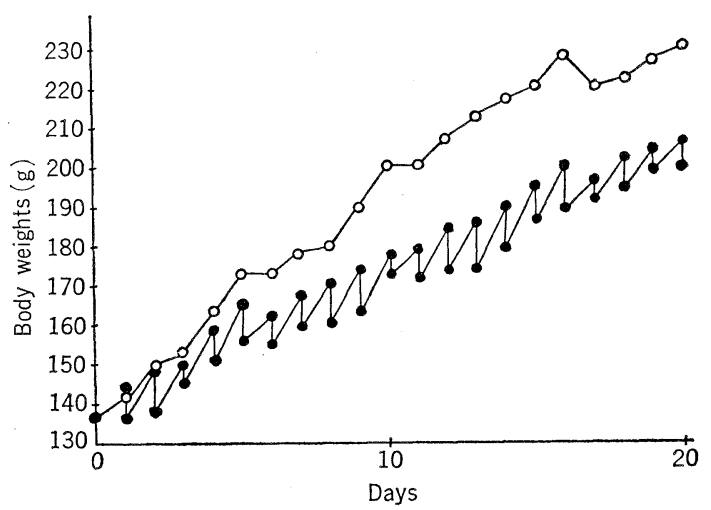

Fig. 2. Effect of forced swimming exercise on the body weight of rat. exercise. Rats were weighed before and after exercise. $O$, control. 
Effect of swimming exercise on anserine and carnosine contents of rat gastrocnemius muscle is shown in Table 3. Anserine content in exercised rat was equal to that of the control rat, but carnosine content was half that of the control.

\section{Anserine and carnosine contents of granuloma and sarcoma}

Neither anserine nor carnosine was detected in the three cases of granuloma shown in Table 4. Walker Carcinosarcoma contained 5.808 and $2.077 \mathrm{mg}$ of DNA

Table 4. Anserine and carnosine contents in rat granuloma and Walker Carcinosarcoma.

\begin{tabular}{lccc}
\multicolumn{1}{c}{ Sample } & Number used & $\begin{array}{c}\text { Anserine } \\
\mu \text { mole/wet tissue }(\mathrm{g})\end{array}$ & $\begin{array}{c}\text { Carnosine } \\
\mu \text { mole/wet tissue (g) }\end{array}$ \\
\hline Granuloma & 3 & ND & ND \\
Walker Carcinosarcoma & 3 & ND & ND \\
Gastrocnemius muscle & 3 & $1.420 \pm 0.148$ & $5.170 \pm 0.646$ \\
\hline
\end{tabular}

Mean \pm standard error, ND; not detected.

and RNA per $g$ of wet tissue, respectively. On the other hand, intact gastrocnemius muscle had 0.531 and $1.215 \mathrm{mg}$ of DNA and RNA per $\mathrm{g}$ wet tissue, respectively. These results indicated that the sarcoma grows by rapid cellular differentiation. However, the sarcoma contained neither anserine nor carnosine (Table 4).

Anserine and carnosine contents in red and white muscle fibers of the skeletal muscles of rabbit

Rabbit gastrocnemius, adductor magnus and latissimus dorsi muscles were individually separated into red and white muscle portions. Protein, DNA, RNA and creatinine contents were estimated and the results were summarized in Table 5.

Table 5. Protein, DNA, RNA and creatinine contents in rabbit red and white muscle.

\begin{tabular}{lcccc}
\hline & $\begin{array}{c}\text { Protein } \\
\mathrm{g} / \text { wet tissue }(\mathrm{g})\end{array}$ & $\begin{array}{c}\text { DNA } \\
\mathrm{mg} / \text { wet tissue(g) }\end{array}$ & $\begin{array}{c}\text { RNA } \\
\mathrm{mg} / \text { wet tissue(g) }\end{array}$ & $\begin{array}{c}\text { Creatinine } \\
\mathrm{mg} / \text { wet tissue(g) }\end{array}$ \\
\hline $\begin{array}{l}\text { Red muscle } \\
\text { Gastrocnemius }\end{array}$ & $0.279 \pm 0.014$ & $0.944 \pm 0.059$ & $0.540 \pm 0.057$ & $0.929 \pm 0.054$ \\
$\quad \begin{array}{l}\text { Adductor magnus } \\
\text { Latissimus dorsi }\end{array}$ & $0.220 \pm 0.018$ & $0.817 \pm 0.062$ & $0.574 \pm 0.182$ & $0.988 \pm 0.035$ \\
\hline $\begin{array}{l}\text { White muscle } \\
\text { Gastrocnemius }\end{array}$ & $0.207 \pm 0.015$ & $0.425 \pm 0.014^{* *}$ & $0.438 \pm 0.090$ & $1.096 \pm 0.029$ \\
$\quad \begin{array}{l}\text { Adductor magnus } \\
\text { Latissimus dorsi }\end{array}$ & $0.194 \pm 0.010$ & $0.397 \pm 0.013^{* *}$ & $0.678 \pm 0.164$ & $1.078 \pm 0.011$ \\
& $0.200 \pm 0.022$ & $0.386 \pm 0.011^{* *}$ & $0.392 \pm 0.089^{*}$ & $1.084 \pm 0.014^{*}$ \\
\hline
\end{tabular}

Mean \pm standard error, $* p<0.05, * * p<0.01$.

On the comparison of red and white muscle fibers of these three skeletal muscles, protein cotents in red muscle were greater than in white muscle but not significant. DNA contents in red muscle were significantly higher than those in white muscle. 
Anserine and carnosine contents in red and white muscle are shown in Figs. 3 and 4. Anserine contents in rabbit white muscle fibers were 12-17 $\mu$ moles per $\mathrm{g}$ of wet tissue and this value was 10 times higher than that of anserine in red muscle fibers (1-2 $\mu$ moles/g of wet tissue). Also, the carnosine content in white muscle fibers was two times higher than that in red muscle fibers.

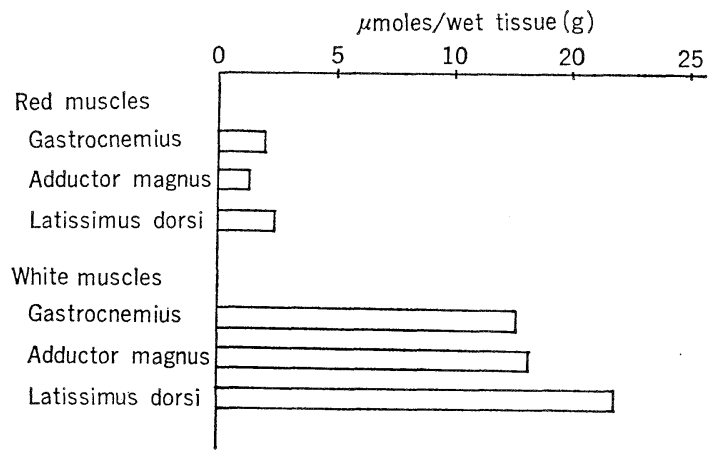

Fig. 3. Anserine content in rabbit red and white muscle. Values are mean of three samples.

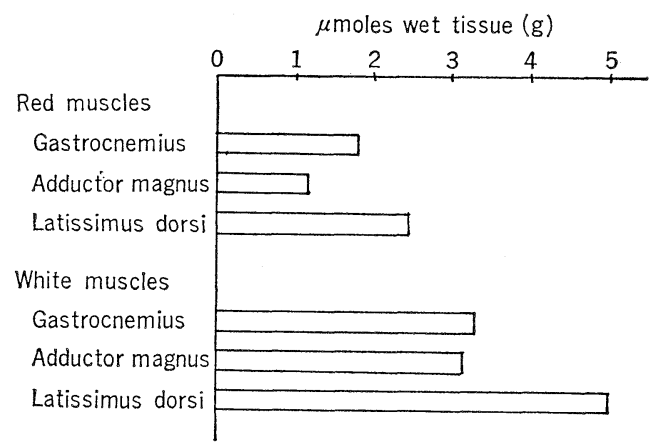

Fig. 4. Carnosine content in rabbit red and white muscle. Values are mean of three samples.

Average $\beta$-alanine contents of gastrocnemius, adductor magnus and latissimus dorsi muscle were $0.175 \mu$ moles $/ g$ of wet tissue in red muscle and $0.455 \mu$ moles $/ \mathrm{g}$ of wet tissue in white muscle. Beta-alanine content in white muscle was about 2.5 times higher than that in red muscle. Histidine, one of the components of carnosine structure, was $0.460 \mu$ moles/g of wet tissue in red muscle fibers and $0.111 \mu$ moles $/ \mathrm{g}$ of wet tissue in white muscle fibers. $\mathrm{N}^{\pi}$-Methylhistidine, one of the components of anserine structure, was not detected in either red or white muscle fibers.

\section{DISCUSSION}

Accelerative effects of anserine and carnosine on actomyosine ATPase (17) 
and on calcium accumulation of sarcoplasmic reticulum (18) have been reported. The anserine and carnosine contents of chicken muscle were not detected one day after hatching, but began appearing on the 6th day after hatching (19). However, the direct effect of anserine and carnosine on muscle contraction has not yet been shown. It is difficult to recognize the direct relationship between carnosine and muscle contraction. At least from our results, we can not neglect possible relation between anserine or carnosine and muscle contraction.

FUKADA (20) has reported that anserine content was decreased by denervation. However, in the present study the anserine content did not change by denervation (Tables 1 and 2). The decrease of carnosine content in the gastrocnemius muscle was evident and the alteration was more significant than that of the wet weight and DNA content of the muscle. The wet weight of gastrocnemius muscle was immediately decreased after denervation, but the decreased level of wet weight was maintained for three weeks. The effect of denervation on the carnosine content appeared slowly and in the third week after denervation. The alteration was the most significant (Table 2), suggesting the slow metabolism of carnosine.

Considering not only the restriction of muscular contraction, but also the inhibitory supply of nutrients to the gastrocnemius muscle by ischiamic denervation, the effect of Gibney's fixation on anserine and carnosine contents was investigated. It was difficult to restrict the movement for a long time by Gibney's fixation, because Gibney's bandage was damaged by the rat itself. One week after the fixation, the carnosine content of the fixed leg gastrocnemius muscle showed a decrease compared to the intact gastrocnemius muscle (Table 3).

There are two possibilities of the decrease of carnosine content by denervation; one is the decrease of carnosine synthesis and the other is an increase of its degradation. The probability of the decrease of carnosine synthesis is low because of the maintenance of the anserine level to the control after denervation. Though carnosinase activity of rat skeletal muscle is low (21), the activity was increased by about two times by denervation. This suggests that the increased carnosinase activity by denervation caused at least the decrease of carnosine content.

As it has been reported that anserine and carnosine are synthesized in a tumor $(10)$ and that they are localized in skeletal muscle $(2,3)$, the peptides contents in sarcoma and granuloma in skeletal muscle were determined. However as observed, human sarcoma (1), rat sarcoma and granuloma did not contain anserine nor carnosine (Table 4). Both are contained in the muscle cells.

Both anserine and carnosine levels in white muscle fibers, the so-called fast twitch muscle, are higher than those in red muscle fibers, the so-called slow twitch muscle. Especially the difference between red and white muscle fibers was significant in anserine content. Namely, white muscle, which is more active than red muscle, contains more anserine and carnosine than red muscle, suggesting some relation between these peptides and muscular contraction.

From the results showing a significant decrease in muscular carnosine contents 
by ischiamic denervation and the higher contents of anserine and carnosine in white muscle fibers than red muscle fibers, it is suggested that these peptides have some relation to muscular function.

The authors are indepted to Miss F. Tsunemori, Mr. M. Ashida and Mr. A. Nishino for their technical assistance.

\section{REFERENCES}

1) Tamaki, N., Izzumi, H., Masumitsu, N., Kubota, H., and Hama, T. (1976): Species specificity on the contents of anserine and carnosine. Yakugaku Zasshi, 96, 1481-1486.

2) Tallan, H. H., Moore, S., and Stein, W. H. (1954): Studies on the free amino acids and related compounds in the tissues of the cat. J. Biol. Chem., 211, 927-939.

3) Hama, T., Tamaki, N., Izzumi, H., and Miyamoto, F. (1970): Effect upon the contents of $\beta$-alanine, anserine and carnosine in several organs of rat by the administration of 6-azauracil, $\beta$-alanine or carnosine. Eiyo To Shokuryo (J. Jpn. Soc. Food Nutr.), 23, 175-179.

4) Winnick, R. E., and Winnick, T. (1959): Carnosine-anserine synthetase of muscle. I. Preparation and properties of a soluble enzyme from chick muscle. Biochim. Biophys. Acta, 31, 47-55.

5) Kalyankar, G. D., and Meister, A. (1959): Enzymatic synthesis of carnosine from B-alanyl adenylate and histidine. J. Am. Chem. Soc., 81, 1515-1516.

6) Kalyankar, G. D., and Meister, A. (1959): Enzymatic synthesis of carnosine and related $\beta$-alanyl and $\gamma$-aminobutyryl peptides. J. Biol. Chem., 234, 3210-3218.

7) Aonuma, S., Hama, T., Tamaki, N., and Okumura, H. (1969): Orotate as a $\beta$-alanine donor for anserine and carnosine biosynthesis, and effects of actinomycin $\mathrm{D}$ and azauracil on their pathway. J. Biochem., 66, 123-132.

8) AOnuma, S., Hama, T., and TAMAKI, N. (1970): Interconversion of the tritium labeled anserine and carnosine in rat liver and muscle. J. Biochem., 68, 581-583.

9) TAMAKI, N., and HAMA, T. (1976): Effects of thyroid hormone and dietary protein levels on the contents of anserine and carnosine in gastrocnemius muscle of rats. Eiyo To Shokuryo (J. Jpn. Soc. Food Nutr.), 29, 317-324.

10) Lebedeva, S. B. (1969): Synthesis of carnosine and anserine in tumors. Ukr. Biokhim. Zh., 41, 65-67.

11) Nagai, K., Kodaira, H., Kabutake, H., Takano, H., and OKi, T. (1974): Further effects of carnosine ( $\beta$-alanyl-L-histidine) on granulation and wound healing. J. Nihon Univ. Sch. Dent., 16, 29-34.

12) Konno, K., and Tetsuka, T. (1963): The connective tissue. I. The granuloma formation induced by the implantation of Japanese agar. J. Biochem., 53, 231-237.

13) Dawson, D. M., and Romanul, F. C. A. (1964). Enzymes in muscle. II. Histochemical and quantitative studies. Arch. Neurol., 11, 369-378.

14) Burton, K. (1956): The conditions and mechanism of the diphenylamine reaction for the colorimetric estimation of deoxyribonucleic acid. Biochem. J., 62, 315-323.

15) Folin-Wu (1919): A system of blood analysis. J. Biol. Chem., 38, 81-110.

16) Gornall, A. G., Bardawill, C. J., David, M. M. (1949): Determination of serum proteins by means of the biuret reaction. J. Biol. Chem., 177, 751-766.

17) Avena, R. M., and Bowen, W. J. (1969): Effects of carnosine and anserine on muscle adenosine triphosphatases. J. Biol. Chem., 244, 1600-1604.

18) LopinA, O. D., and Boldyrev, A. A. (1975): Effect of carnosine and anserine dipeptides on the accumulation of calcium (2-) by fragments of sarcoplasmic reticulum. Dokl. Akad. 
Nauk SSSR, 220, 1218-1221.

19) McManus, I. R., and Benson, M. S. (1967): Studies on the formation of carnosine and anserine in pectoral muscle of the developing chick. Arch. Biochem. Biophys., 119, 444-453.

20) FukAdA, R. (1968): Physiological significance of carnosine and anserine in muscle-contraction. IV. Change in the content of carnosine and anserine in rat muscles under histidine deficiency and after denervation. Wakayama Igaku (J. Wakayama Med. Assoc.), 19, 285292.

21) Wood, T. (1957): Carnosine and carnosinase in rat tissue. Nature, 180, 39-40. 